(Bureau of Forestry, Government of Formosa), Bunzo Hayata continues his descriptive account of the flora of this island. The volume contains studies of genera of a large number of families of flowering plants, and includes descriptions of 139 new species; the arrangement follows the system of Bentham and Hooker's "Genera 'Plantarum." The descriptions (in Latin) are full and clear, and the volume is remarkably well illustrated with text-figures and plates. Two new genera are established, one, Dolichovigna, a climbing bean near Phaseolus and Vigna; the other, Pseudosmilax, a member of the family Liliaceæ, and intermediate between Smilax and Heterosmilax. Nine genera are also recorded as new to the fiora of the island, which so far as is at present known includes 3608 species of flowering plants representing 1185 genera and 160 families.

In the Journal of Ecology (vol. viii., No. I) Miss L. S. Gibbs gives an account of the phytogeography and flora of the mountain-summit plateaux of Tasmania based on her own observations and collections. The vegetation of the island may be divided into three principal plant formations: (I) The austral-montane flora of the mountain-summit plateaux, which represent the remains of the huge lava plateau of which the island formerly consisted. The major and most interesting portion of the endemic flora is entirely limited to these summit plateaux; one of the peculiar features is the almost complete absence of herbaceous plants. (2) The mixed forest of the west coast, not very rich in species and characterised more by denseness of growth than by height. There is a marked endemic element in this flora which probably originated on the higher lands. (3) Eucalyptus formation, occupying the greater part of the island, consisting mainly of secondary open forest, and purely Australian in type. A description is given of the various portions of isolated tableland which form the mountains of the island and at no point exceed $5000 \mathrm{ft}$, and the writer describes the chief plant-associations, enumerating the plants which she collected in each. On the most exposed and highest levels a mosaic of small moss-like plants is developed, with inconspicuous flowers, forming a hard, even surface. This is succeeded by a mountain shrubbery, the dominant association of the more exposed portions of the plateau summits. Lower come forest-associations in succession, namely, dwarf mountain forest, low mountain forest, and Eucalyptus scrub. In conclusion, the author refers to the marled relation between the mountain flora of North-West New Guinea, the subject of a former paper, and the so-called "Antarctic flora" of the southern hemisphere. Recent work on meteorological conditions provides an explanation of this relation, namely, in the persistent north-west wind of high altitude over the mountains of New Guinea and across the Australian continent. Seeds transported by this agency would be precipitated in southern latitudes, where they remain within the radius of the persistent westerly winds and gales of the Antarctic seas.

A systematic enumeration is given of the species collected on the mountain-summit plateaux and in the mixed forest from September. I9I4, to March, I9I5.

\title{
Origin of Petroleum and Cause of Gas Pressure.
}

THE important volume referred to below is bountifully illustrated with photographs, sections, and maps, and gives a comprehensive account of some $r_{50}$ square miles in the midst of the Californian oilfields, a territory which provides nearly half the oil which the State produces, and includes its greatest oilfield. Here, too, is the famous "Lakeview Gusher," which yielded 8,000,000 barrels of oil in eighteen months. The area has been discussed previously both by State and Federal geologists, notably some ten years ago by $\mathrm{R}$. Arnold, $\mathrm{H}$. Johnson, and $R$. Anderson in Bulletins 406 and $47 \mathrm{I}$, but since that time there has been much further development, and many new facts are available.

The worls contains a wealth of information which is rendered easily accessible by its systematic arrangement and clear table of contents. The book commences with a brief "Summary of Results," which is followed by an informative bibliography. "Stratigraphy," which occupies 34 pages, is dealt with under the headings of the various formations. Then follow "Structure" (pp. 54-63) and "Petroleum" (pp. 63-87), whilst a detailed description of the "Productive Field" occupies the latter half of the book. In the pocket at the back of the volume is a geologic map of the region and large-scale topographic and structure maps of the oilfield, together with many sections across the productive area.

The main scientific inferences differ little from those set forth in the earlier bulletins. It is made clear that the petroleum was generated within the Tertiary deposits, which are at least $18,000 \mathrm{ft}$. in thickness, ranging from Eocene to Pliocene. Regard-

1 United States Geological Survey, Professional Paper No. r16: "The Sunset Midway Oil Field of California." Part i., "Geology and Oil Resources." By R. W. Pack. Pp. 179.

$$
\text { NO. } 2689 \text {, VOL. IO7] }
$$

ing the origin of the oil, the author's explanation is that previously formulated by Arnold and Anderson; but he does not ascribe the source of the carbon wholly to the diatoms and foraminifera. "The petroleum has originated in the diatomaceous shale formations, chiefly from the alternation of organic matter contained in diatoms and foraminifers, but probably in part also from the alteration of terrestrial vegetal debris." Later "the oil has collected in par't in sandy beds that are intercalated with the [diatomaceous] shale, but chiefly in the porous beds of younger formations that rest unconformably upon the shale."

With reference to migration and accumulation, the author affirms that much of the oil in the pools "has migrated from the beds beneath the San Joaquin Valley to the foothills and collected in the small anticlines that extend from the hills out into the valley." The reservoirs of oil are now chiefly in the later Tertiary "[Miocene or Pliocene] sandy beds that rest unconformably upon the diatomaceous shale."

Some interesting matters are discussed in connection with the gas pressure and concerning chemical reactions on the petroleum within the oilsands. The pressure in these fields is not proportionate to depth, and usually is considerably in excess of the theoretical "hydrostatic pressure." The author holds that the oil, whilst within the reservoirs, has been affected by chemiral reactions with minerals. In particular, oxidation by sulphate-laden waters has produced a marginal ring of heavy tar around the pool where its bottom rests upon the under-water. This tar seals the oil pool within a definite space, and any further quantities of gas generated from the oil can be accommodated only by increase of pressure. Such conditions probably account for the great gusherwells of this region. 